\title{
Impact of Excess Control, Ownership Structure and Corporate Governance on Firm Performance of Diversified Group Firms in Pakistan
}

\author{
Waseem Ullah $^{1}$, Shahid $\mathrm{Ali}^{2}$, Sajid Mehmood ${ }^{3}$
}

\begin{abstract}
This paper attempts to explore the effect of excess control, ownership structure and corporate governance on firm performance in Pakistan. The study takes a sample of 184 non-financial sectors' group firms listed on the Karachi Stock Exchange (KSE) covering a period from 2004 to 2012. The multiple regression models are applied using panel data framework to test the significance of relationship. The results are consistent with the findings of the prior studies conducted in both advanced and emerging economies. The results show that firm ownership is a strong influential factor in affecting firm performance in Pakistan. Both inside ownership and ownership concentration are negatively related to firm performance consistent with divergence of interest effect and entrenchment effect. However, inside ownership squared is strongly positively related to firm performance indicating that inside ownership beyond a certain threshold level started to influence firm performance positively consistent with incentives effect. Ownership disparity affects strongly negatively the financial performance of group firms consistent with the divergence of interest effect. Institutional ownership contributes positively towards firm performance. Noticeably, board independence and outside block holdings play a significantly positive role in affecting financial performance of the group firms in Pakistan. The results show strong evidence that ultimate controllers in group firms use complex ownership and pyramidal structures to extend their ultimate control over many firms with least cash flow rights. The higher the divergence between ownership and control, the greater the potential of the ultimate controllers exerted their entrenched behavior in group firms. These results highlight the internal corporate governance problems faced by the group firms and suggest the need for strengthening the corporate governance mechanism in Pakistan.
\end{abstract}

1 PhD Scholar, Capital University of Science and Technology, Islamabad. Email: waseem.ullah81@ gmail.com

2 Assistant Professor, Institute of Management Sciences, Peshawar. Email: shahid.ali@imsciences.edu. pk

3 Lecturer, Department of Management and Administrative Sciences, University of Gujrat, Gujrat. Email: sajid@uog.edu.pk

ARTICLE HISTORY
\begin{tabular}{lll}
18 Nov, 2016 Submission Received & 9 Dec, 2016 & First Review \\
\hline 9 Jan, 2017 Revised Version Received & 4 Mar, 2017 & Second Review \\
\hline 11 Apr, 2017 Revised Version Received & 2 May, 2017 & Accepted
\end{tabular}


Key Words: Business Groups; Corporate Governance; Ownership Structure; Excess Control; Ownership-control Disparity; Firm Performance.

\section{Introduction}

Business groups possess the largest part of productive assets in Pakistan like many other emerging economies. The phenomenon is that most of the group firms are not widely held rather these have dominant shareholders (Villalonga \& Amit, 2006; Estrin, Poukliakova, \& Shapiro, 2009). These dominant shareholders exert entrenched behavior and may engage in expropriation of external shareholders (Djankov, La Porta, Lopez-de-Silanes, \& Shleifer, 2008; Bertrand, Johnson, Samphantharak, \& Schoar, 2008). There is another common problem in these firms that ultimate controllers might extend their control through a variety of complex ownership structures. There exist stock pyramids, dual class share structure and cross shareholdings those may bring the ultimate controller in a position to control many firms simultaneously with least cash flow rights. These factors cause divergence between ownership and control. The tendency of lower participation in corporate voting by the general public further augments ownership-control disparity (Bebchuk, Kraakman, $\mathcal{G}$ Triantis, 2000; Ali, Chen, \& Radhakrishnan, 2007; Attig, 2007).

Agency costs are at the central place in the managerial issues of group affiliated firms. A number of researchers suggest corporate ownership as the root cause of serious agency conflicts in these firms. The focus of corporate governance shifts away from principal-agent (P-A) conflicts to principal-principal (P-P) conflicts e.g., conflicts between controlling shareholder and minority shareholders (Claessens, Djankov, \& Lang, 2000). The controlling shareholder decides not only how to run the firm but also how the profits of firm should be distributed. Agency costs are troublesome due to divergence of interest effect and may affect firm performance adversely particularly in those countries where corporate governance system is not well developed (Lan \& Wang, 2004). It puts pressure on the board to strengthen firm's internal monitoring and governance practices with true spirit of law besides the compliance of external corporate governance system.

Globally renowned that corporate governance system has a significant impact on firm performance. Since the firms got mature and become more adaptive to well defined corporate governance practices, these enhance the ability of management in utilizing firm resources and it ultimately may contribute to higher firm performance. It is vital for the development of a sound financial system in the country that benefits should flow to the shareholders proportionately to their shareholdings. Jensen and Meckling (1976) propose that monitoring and incentives alignment are the major tools recommended by agency theorists to minimize agency problems (Shah, 2009). The corporate governance system strengthens the monitoring of the firm. It ensures 
the protection of equity providers particularly minority shareholders, beneficial in building their confidence and hence helps in controlling agency conflicts.

In this study, an effort is made to investigate the impact of corporate ownership and corporate governance practices on firm performance. The study contributes in many folds. First, the principal contribution lies in the construction of a sample of 184 group affiliated firms listed on Karachi Stock Exchange. The present study focuses business groups because these are the most visible in the business environment of Pakistan. Despite the historical success in the past (White, 1974), a number of studies for instance Gohar and Karacaer (2009) and Ghani, Haroon, and Ashraf (2008) document that group firms tend to decline in performance. The present study put efforts highlighting the major corporate governance problems faced by group firms and attempt answering why group firms tend to decline in performance.

Second, business groups have heterogeneous features that can influence firm performance with different strength (Kim, Hoskisson, \& Wan, 2004; Khanna \& Yafeh, 2005; Lins \& Servaes, 2002). The study examines the moderating role of group diversification in explaining the corporate governance-performance relationships. Third, the ultimate controllers in business groups extend their control in excess of their cash flow rights. It is important to examine the impact of ownership-control disparity (excess control) on group firms' performance. Forth, the study examines if inside ownership-performance relationship is linear or non-linear in nature? Finally, the present study investigates the role of institutional investors, outside block holders and independent directors in mitigating of the corporate governance problems inherent in the business groups' structure (George \& Kabir, 2008). The study fills the gap in finance literature and provides theoretical support to regulatory bodies responsible for corporate governance mechanism in Pakistan.

\subsection{Business Groups in Pakistan}

Business groups are the most visible feature of business environment in many emerging and transitional economies such as Pakistan, India, China, Hong Kong; South Korea among others (Essen, 2011). Business groups are set of legally independent firms connected each other by formal and informal ties. Formal ties include cross ownership and informal ties include cross directorship and social ties. These ties create trust worthy relationship among members which bound them taking coordinated actions (Khanna \& Rivkin, 2001; George \& Kabir, 2008; He, Mao, Rui, \& Zha, 2013).

In Pakistan, business groups flourished aggressively in the past during 1950's and early 1960's in response to extensive market failures and favourable Government policies (White, 1974b; Ghani et al., 2008). Many institutions that support business 
activities were absent in the country and business groups fill that gap. The business groups share resources like skills and labour, capital, information, brand names and markets among member firms (Ghani et al., 2008). Further, they got favours through political connections in getting loans, licences of foreign exchange and import quotas, etc. The resources asymmetries caused the emergence of a class of industrialists known as '22 families' and latter 'business groups' in Pakistan (White, 1974). However, the recent studies for instance Gohar and Karacaer (2009) and Ghani et al. (2008) document that business groups' affiliated firms have declined in financial performance and these suggest agency conflicts as the root cause of lower firm performance in Pakistan.

The study is structured as follows. In the first section, introduction of the study is given. In the second section, existing literature review is presented. The research methodology is discussed in the third section followed by results and discussion in the forth section and finally conclusion is drawn in the fifth section of the study. The study also presents recommendations and suggestions in the final section.

\section{Literature Review}

\subsection{Corporate Ownership and Firm Performance}

\subsubsection{Managerial ownership and firm performance}

Separation of ownership and control is the basis for agency costs in the corporations. Besides the growth of business groups, there are also many evidences that group firms fall into severe agency problems. In Pakistan, most of group firms are privately held family controlled firms and with the growth of their business assets, they get a few of the firms listed on stock exchange. There may be other considerations at play but the primary objective of getting firm listed may include getting access to capital market in terms of general public resources. Although, any of the group members occupies the key executive position in the firm or represent the board, thus it mitigates the traditional agency conflicts between principal and agent (Ali et al., 2007). However, business groups are prone to agency conflicts among the controlling shareholders and minority shareholders. The group members achieve an ultimate control over many firms with least capital investments.

Inside ownership is the major tool that aligns the incentives of controlling shareholders with those of minority shareholders and thus may help in mitigating the agency conflicts among them. The inside ownership-performance relationship may be non-linear in nature. As the group members may achieve an ultimate control of the firms with least cash flows by using control enhancing devices, therefore, inside ownership at lower levels may affect negatively the firm performance. The group 
members may be motivated to engage in tunneling the resources from those firms where they have least cash flow rights to other firms where they have higher cash flow rights. Any discount in market price of share by the minority shareholders will cost them least. On the other hand, inside ownership at higher levels (inside ownership squared) may affect positively the group firms' performance. It will discourage the ability of the group members engage in tunneling because the discount in share prices by the minority shareholders will cost to the controlling shareholders in proportionate to their shareholdings (La Porta, Lopez-de-Silanes, \& Shleifer, 1999).

Hypothesis $\mathbf{1}_{\mathbf{a}}$ : There is a significant negative relationship between inside ownership and financial performance of group affiliated firms.

Hypothesis $1_{b}$ : There is a significant positive relationship between inside ownership squared and financial performance of group affiliated firms.

\subsubsection{Ownership concentration and firm performance}

In Asian countries, ownership is concentrated in the hands of few shareholders of the firm (Claessens et al., 2000). Ownership concentration enhances the ability of dominant shareholders in monitoring the managers. It aligns the interests of dominant shareholder with those of minority shareholders if his control rights are equal to his cash flow rights (Bennedsen \& Nielsen, 2010). It ensures that dominant shareholder will not expropriate firm resources because any discount in price may cost him more than his private benefits (Bozec \& Laurin, 2008). However, it is not a necessary condition for the dominant shareholder of not exploiting the minority shareholders. It depends upon his ability and motivation in expropriation of firm resources. If private benefits of dominant shareholder are greater than his cash flows, he may attempt tunnelling firm resources detriments to minority shareholders. As cross shareholdings among the group affiliated firms are more common in the ownership structure of the group firms and these shareholdings (indirect investments) are primarily motivated to extend the control over firms. Therefore, ownership concentration is expected to affect firm performance negatively due to entrenchment effect.

Hypothesis 2. There is a significant negative relationship between ownership concentration and financial performance of group affiliated firms.

\subsubsection{Divergence between ownership and control and firm performance}

There is a common problem in the group firms that ultimate controller attempts enhancing his control over many firms. The interpersonal trust worthy relationship among group members enables them achieving an ultimate control over the firm even with lesser cash flow rights. They may use different control enhancing devices like 
cross ownership, cross directorate-ship, dual class share structure and most importantly stock pyramids. More than one-third listed firms worldwide constitute as pyramids (La Porta et al., 1999) and this is even more in case of Pakistan (Ikram \& Naqvi, 2005). These complex ownership structures cause divergence of ownership and control.

The excess control rights than cash flow rights motivate ultimate controller making private benefits through diversion of resources from one firm with least cash flow rights to another with higher cash flow rights (La porta et al., 1999; Omrane \& Dev, 2009). Expropriation of firm resources may be through different ways like inside trading, transfer pricing, and sub-optimal investment decisions, employing incompetent relatives on key executive positions and excessive salaries and perquisites. He will not worry about the discount in market price by external shareholders because it will cost him least.

There are many evidences in emerging countries and even in wealthy common law countries that divergence (disparity) between ownership and control affects firm performance negatively. Villalonga and Amit (2006) find evidence that control enhancing devices used by firms affect their performance adversely. Bozec and Laurin (2004) document that an ultimate controller with control rights in excess of cash flow rights affect firm performance inversely if his cash flows are small in Canada. Attig, Fischer, and Gadhoum (2004) find negative impact of pyramidal ownership on firm value. Many other studies find similar results in Asian countries including Claessens, Djankov, Fan, \& Lang (2002); Lins (2003); Lemmon and Lins (2003); Joh (2003), and Lee, Peng, and Lee (2008).

Hypothesis 3. There is a significant negative relationship between ownership-control disparity and financial performance of group affiliated firms.

\subsubsection{Institutional ownership and firm performance}

Theoretical concerns regarding the role of institutional shareholders in corporate governance are inspired by discussions of institutional investors' activism. It is suggested that institutional investors are the most effective device in supervision of management activities. As the minority shareholders are not part of the board, they feel satisfaction if institutional investors are present in the board thus helps in mitigating agency problems of ownership dispersion (Demsetz \& Lehn, 1985; Shleifer \& Vishny, 1986; Cornett, 2008). Institutional investors are highly activated by performing trustee activities to attain higher investment performance. Depending upon contribution and power of the institutional shareholders, they may cause growing stock liquidity and enhanced market valuation which signals other investors about the higher performance of firm (Kyereboah-Coleman, 2007). Moreover, institution- 
al ownership may play an effective role in moderating the entrenched behavior of ultimate controller in group firms and therefore is expected to have a strong positive relationship with firm performance.

Hypothesis 4: There is a significant positive relationship between institutional ownership and financial performance in group affiliates of group affiliated firms.

\subsection{Corporate Governance and Firm Performance}

The ownership concentration and pyramidal ownership structures ${ }^{4}$ may be harmful for the external shareholder because they lead to entrenchment and divergence of interest effect. It is very important for the sound development of a financial system that cash flows should flow to shareholders proportionately to their shareholdings. Cash flows are the main source of incentives for an ultimate controller in a firm which aligns his interest with external shareholders. Monitoring becomes essential for discouraging the ability of expropriation of firm resources by an ultimate controller particularly for those firms where exists a potential of making higher private benefits than cash flows. There is an utmost need for an effective corporate governance system playing its due role in monitoring of these firms.

\subsubsection{Board independence and firm performance}

A number of studies in the field of corporate governance stress the need for increase in proposition of non-executive directors in the board. The presence of non-executive directors decreases agency costs because it assures the protection of minority shareholders' rights (Hutchinson \& Gul, 2004). Fama and Jensen (1983) argue that non-executive directors guarantee the effective running of the firm and supervise the management to protect their reputation in the market. Rosenstei and Wyatt (1990) find an increase in firm performance with increase in proposition of non-executive directors in the board. Baysinger and Butler (1985) and Klein (1998) observe an insignificant relationship of percentage of outside directors with firm performance.

However, the effectiveness of the non-executive directors depends upon spirit and integrity of law in the eyes of management. In group firms, mostly the non-executive

4 Pyramidal ownership structures are the most common mechanism used by the business groups in order to achieve an ultimate control over many firms. This refers to the situation where a group firm owns chunk of shareholdings in other firms at different layers. For example, a wholly owned group firm A owns 80 percent shares of firm $B$ and firm $B$ owns 80 percent shares of firm $C$. This business group will have an ultimate control over firms A, B $\mathcal{E}$ C. It will have an ultimate control of 80 percent with effective cash flow rights of 64 percent (80\%X80\%) in firm C. The business groups use such pyramidal ownership structures to control many firms simultaneously with lesser cash flow investments which widen the gap between cash flow rights and control rights of the ultimate controllers in business groups that motivate them tunneling firm resources away at the expense of minority shareholders. 
directors come in connection with sister group firms just for compliance of requirements of law; such arrangements may make the traditional governance practices like presence of non-executive directors' redundant. Young (2000) and Dedman (2002) examine the performance impacts of board composition before and after the release of Cadbury Report and find that managerial entrenchment reduces if non-executive directors are not increased subsequent the obligations concerning board structure. Therefore, non-executives may be a burden on the firm and may affect firm performance negatively.

Hypothesis 5. There is a significant relationship between board independence and financial performance in group affiliates.

\subsubsection{Presence of outside block holdings and firm performance}

A bulk of corporate governance literature presents agency problems arising from two extreme ownership structures e.g., $100 \%$ small shareholders or one large shareholder with many small shareholders. Investors value differently for those firms with multiple block holders than single large block holder or widely held firm. In first case, small shareholders lack monitoring ability whereas a single large controlling shareholder is fully entrenched and may harm minority shareholders (Shleifer \& Vishny, 1997; King \& Santor, 2008). The presence of outside block holders enhances the ability of firm in monitoring of managers as well discourages the controlling shareholders' ability in tunneling firm resources. The outside block holders may include individuals as well as a variety of institutional block holders like corporations, domestic and foreign institutional investors. The representatives of the outside block holders possess the ability as well as motivation to influence board decisions for the growth and safeguard of their investments. The interests of outside block holders are in alignment with those of minority shareholders and it helps in reducing agency costs.

Hypothesis 6. There is a significant positive relationship between presence of outside block holdings and financial performance in group affiliates.

\section{Methodology}

The study employs a sample of 184 non-financial KSE listed Pakistani groups affiliated firms for a period of 2004-2012. ${ }^{5}$ The sample comprehensively covers almost all the non-financial sectors. In order to make our results comparable with earlier studies, the study excludes financial service firms like mutual funds, commercial

5 There is no source compiling ownership data and other corporate governance indicators. The researchers scan annual reports in order to collect the required data. Further, accounting variables data is collected from the publications of State Bank of Pakistan "Balance sheet analysis of joint stock companies listed on Karachi Stock Exchange". Stock market prices are obtained from the website of "Business Recorder". 


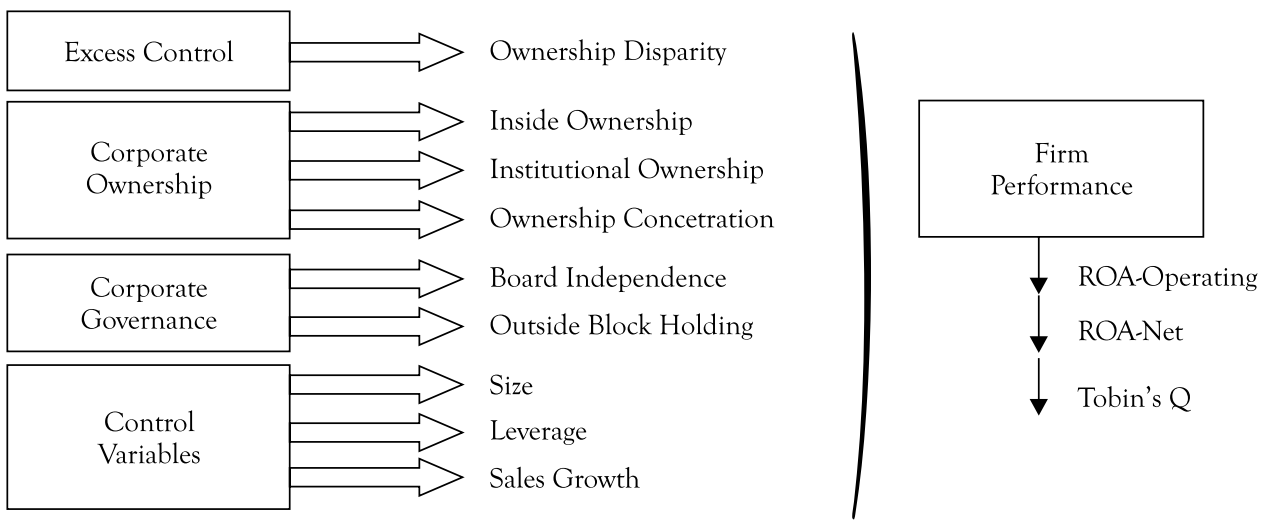

Figure 1: Conceptual Model

and investment banks, insurance companies, etc., as well as government and foreign subsidiaries (Shah, 2009; Abdullah, Shah, Iqbal, \& Gohar, 2011a; Abdullah, Shah \& Khan, 2012; Arshad \& Javid, 2014; Yousaf \& Hasan, 2016). Group firms are defined on the basis of certain criteria including cross-ownerships and pyramids, cross-directorate-ships and social ties 6 .

The study uses random effect Generalized Least Square regression model due to several reasons. First, group affiliation may also share unobservable characteristics like managerial talent, group's resource sharing ability, etc., that may cause error term to be correlated. This correlation may cause understated standard errors obtained from OLS (Moulton, 1986). Random effect Generalized Least Square regression approach assumes that observations are independent across groups but may not be independent within groups (Khanna \& Palepu, 2000). Second, the study includes only those group firms whose status of group firm to non-group firm and affiliation to one business group to another business group has not changed during the sample period. Further, the study includes industry dummies which normally do not change over the period. Fixed effect model is not appropriate in such circumstances because fixed effect estimators cannot be computed if regressors do not change within group (Hsu \& Liu, 2008; Yin \& Zajac, 2004; Zeitun, 2009). Third, random effects model is preferred over the fixed-effects model for panels over short periods (Hsiao, 1986; Hsu \& Liu, 2008). Finally, in order to make the results comparable with the earlier studies conducted on group firms (for instance Khanna \& Palepu, 1999 \& 2000; Andres, 2006; Zeitun, 2009), the study uses GLS-random effect model. ${ }^{7}$

6 In order to get information about business groups operating in Pakistan, the researchers scan patterns of shareholding statements of firms and board of directors' information. Further, information is obtained from a book "Who owns Pakistan" (1998) and the website of "Business council of Pakistan".

7 For robustness, the study has also done analyses using OLS and fixed effect models (but not shown for brevity) and these results are consistent with the results of GLS-random effect models. 


\subsection{Model of the Study}

Firm Performance ${ }_{\text {it }}=\beta_{0}+\beta_{1}$ Inside Ownership ${ }_{i t}+\beta_{2}$ Inside Ownership Squared $+\beta_{3}$ Ownership Disparity ${ }_{\text {it }}+\beta_{4}$ Institutional Ownership ${ }_{i t}+\beta_{5}$ Ownership Concentration $+\beta_{6}$ Board Independence ${ }_{i t}+\beta_{7}$ Outside Block Holding ${ }_{\text {it }}+\beta_{8}$ Size $_{\text {it }}+\beta_{9}$ Leverage $_{\text {it }}+\beta_{10}$ Sales Growth $_{\text {it }}+$ error term $_{\text {it }}$

Table 1: Sample composition

\begin{tabular}{|c|c|c|c|}
\hline Sr. \# & Industry & No. of firms & Sample \% \\
\hline 1 & Automobile assembler & 05 & 2.72 \\
\hline 2 & Automobile parts \& accessories & 05 & 2.72 \\
\hline 3 & Cable \& electrical goods & 02 & 1.09 \\
\hline 4 & Cement & 12 & 6.52 \\
\hline 5 & Chemical & 09 & 4.89 \\
\hline 6 & Engineering & 04 & 2.17 \\
\hline 7 & Food \& personal care products & 05 & 2.72 \\
\hline 8 & Glass \& ceramics & 02 & 1.09 \\
\hline 9 & Paper \& board & 06 & 3.26 \\
\hline 10 & Power generation \& distribution & 07 & 3.80 \\
\hline 11 & Sugar & 22 & 11.96 \\
\hline 12 & Synthetics \& rayon & 14 & 7.61 \\
\hline 13 & Textile spinning & 53 & 28.80 \\
\hline 14 & Textile composite & 23 & 12.50 \\
\hline 15 & Vanaspati \& allied industries & 02 & 1.09 \\
\hline 16 & Miscellaneous (jute, leather \& tanneries, & 13 & 7.07 \\
\hline & technology \& communication) & 184 & 100 \\
\hline & & & \\
\hline
\end{tabular}

Table 2: Variable definitions

\begin{tabular}{|c|c|}
\hline Variable & Definitions \\
\hline \multicolumn{2}{|c|}{ Dependent variables: } \\
\hline ROA-Oper & $\begin{array}{l}\text { Return on assets defined as profits before income taxes divided by firm } \\
\text { total assets. }\end{array}$ \\
\hline ROA-Net & It is calculated as net profits divided by total assets of the firms. \\
\hline Tobin’s Q & $\begin{array}{l}\text { Firm Tobin's } Q \text { is defined as market value of equity plus book value of } \\
\text { total liabilities divided by total assets of the firm. }\end{array}$ \\
\hline
\end{tabular}




\begin{tabular}{|c|c|}
\hline Independent variables: & \\
\hline Inside Ownership & $\begin{array}{l}\text { It represents percentage of shares held by directors, their spouses and } \\
\text { children in the firm (Javid \& Iqbal, 2007). }\end{array}$ \\
\hline Ownership Disparity & $\begin{array}{l}\text { This variable represents the divergence between ownership and } \\
\text { control. A dummy variable of } 1 \text { is given for those firms having higher } \\
\text { divergence between ownership and control and } 0 \text { otherwise. A dummy } \\
\text { variable } 1 \text { is given for firms where associated ownership is at least } 40 \\
\text { percent and directors' ownership is less than } 10 \text { percent. }\end{array}$ \\
\hline $\begin{array}{l}\text { Ownership Concentra- } \\
\text { tion }\end{array}$ & $\begin{array}{l}\text { It is measured as percentage of shares held by top five shareholders of } \\
\text { the firm (Javid \& Iqbal, 2007). }\end{array}$ \\
\hline Board Independence & $\begin{array}{l}\text { It is defined as percentage of non-executive directors to total number } \\
\text { of directors in the board (Shah, 2009). }\end{array}$ \\
\hline Outside Block Holding & $\begin{array}{l}\text { A dummy variable } 1 \text { is given if one or more individuals and/or institu- } \\
\text { tional investors (other than directors and associated firms) own more } \\
\text { than } 10 \% \text { shares of the firm individually and otherwise } 0 \text {. }\end{array}$ \\
\hline Size & Firm size is measured as natural logarithm of the total assets. \\
\hline Leverage & $\begin{array}{l}\text { Financial leverage is calculated as dividing total assets of the firm by its } \\
\text { total liabilities (He et al., 2013). }\end{array}$ \\
\hline Sales Growth & $\begin{array}{l}\text { Firm sales growth is obtained as current year sales minus previous year } \\
\text { sales divided by previous year sales (Carney, Shapiro \& Tang, 2009). }\end{array}$ \\
\hline
\end{tabular}

\section{Results and Analysis}

The Table 3 presents the descriptive statistics of the whole sample. The average ROA-Oper, ROA-Net and Tobin's q are 3.35\%, 1.93\% and 1.01 respectively which show that group firms are not highly profitable nor highly market valued. In lines with Claessens et al. (2000) in East Asian countries, the figures of inside ownership and ownership concentration are $31.83 \%$ and $59.36 \%$ respectively. In contrast to Berle and Means (1932) group firms are not widely held rather these have dominant shareholders. The mean value of institutional ownership is $15.28 \%$. The figure of 4.56 for board independence indicates that majority of the directors are non-executive. Similarly, mean value of outside block holding is 0.55 which suggest that outside block holders represent the board of directors of $55 \%$ of the sample firms. These figures portray a reasonable commitment of group firms to the adoption of corporate governance practices in Pakistan.

Table 4 reports the comparative demographics of the firms categorized by group diversification. The statistics show that firms belong to high diversified business groups are significantly more profitable and are well market valued than firms affiliated with (less) diversified business groups (George \& Kabir, 2008). These firms have comparatively lower inside ownership and ownership concentration whereas significantly larger 
Table 3: Descriptive Statistics

\begin{tabular}{|c|c|c|c|c|c|}
\hline Variable & Mean & Median & Maximum & Minimum & Std. Dev. \\
\hline ROA-Oper & 0.0335 & 0.0293 & 0.3085 & -0.2578 & 0.1070 \\
\hline ROA-Net & 0.0193 & 0.0226 & 0.3906 & -0.4769 & 0.1131 \\
\hline Tobin's Q & 1.0053 & 0.8950 & 7.1824 & 0.1513 & 0.5658 \\
\hline Inside Ownership & 0.3183 & 0.2819 & 0.9365 & 0.0000 & 0.2642 \\
\hline $\begin{array}{c}\text { Institutional Own- } \\
\text { ership }\end{array}$ & 0.1528 & 0.1201 & 0.8644 & 0.0000 & 0.1427 \\
\hline $\begin{array}{c}\text { Ownership Concen- } \\
\text { tration }\end{array}$ & 0.5936 & 0.5781 & 0.9520 & 0.2168 & 0.1748 \\
\hline Board Independence & 4.5643 & 5.0000 & 15.0000 & 1.0000 & 1.9348 \\
\hline $\begin{array}{c}\text { Outside Block } \\
\text { Holding }\end{array}$ & 0.5508 & 1.0000 & 1.0000 & 0.0000 & 0.4977 \\
\hline Size & 7.7756 & 7.7827 & 10.9515 & 2.5486 & 1.4276 \\
\hline Leverage & 0.6623 & 0.6364 & 1.9989 & 0.0316 & 0.3090 \\
\hline Growth & 0.1669 & 0.1372 & 0.9951 & -0.6126 & 0.3402 \\
\hline No. of Observations & 964 & & & & \\
\hline
\end{tabular}

ownership stakes of institutional investors. Firms affiliated with high diversified groups are able to achieve an ultimate control over many firms with least direct shareholdings as they use complex pyramidal ownership structures (Bebchuk et al., 2000; Djankov et al., 2008; Baek, Kang, \& Lee, 2006). Further, the institutional investors are concerned with the long-term growth prospects and risk diversification of their investment; they prefer to invest in affiliates of high diversified business groups. Firms affiliated with high diversified business groups are larger in size (in terms of both total assets and sales) than (less) diversified group firms (George \& Kabir, 2008) and however, these do not show any significant difference in corporate governance characteristics like board independence and presence of outside block holding.

Table 4: Firm Characteristics across Diversified and High Diversified Group Firms

\begin{tabular}{|c|c|c|c|c|}
\hline Variable & Firm & Mean & Median & Std. Dev. \\
\hline $\begin{array}{c}\text { Performance } \\
\text { measures: }\end{array}$ & & & & \\
\hline ROA-Oper & Diversified & 0.0244 & 0.0239 & 0.1046 \\
\hline & High diversified & $0.0599^{* * *}$ & $0.0421^{* * *}$ & 0.1095 \\
\hline & All & 0.0335 & 0.0293 & 0.1071 \\
\hline
\end{tabular}




\begin{tabular}{|c|c|c|c|c|}
\hline \multirow[t]{3}{*}{ ROA-Net } & Diversified & 0.0103 & 0.0164 & 0.1112 \\
\hline & High diversified & $0.0452^{* * *}$ & $0.0371^{* * *}$ & 0.1149 \\
\hline & All & 0.0193 & 0.0226 & 0.1131 \\
\hline \multirow[t]{3}{*}{ Tobin's Q } & Diversified & 0.9741 & 0.8864 & 0.4366 \\
\hline & High diversified & $1.0959^{* * *}$ & 0.9152 & 0.8299 \\
\hline & All & 1.0053 & 0.8955 & 0.5658 \\
\hline \multicolumn{5}{|l|}{$\begin{array}{l}\text { Corporate gover- } \\
\text { nance measures: }\end{array}$} \\
\hline \multirow[t]{3}{*}{ Inside Ownership } & Diversified & 0.3603 & 0.3448 & 0.2644 \\
\hline & High diversified & $0.1964^{* * *}$ & 0.1008 & 0.2229 \\
\hline & All & 0.3183 & 0.2819 & 0.2642 \\
\hline \multirow{3}{*}{$\begin{array}{c}\text { Institutional Own- } \\
\text { ership }\end{array}$} & Diversified & 0.1274 & 0.093 & 0.131 \\
\hline & High diversified & $0.2263^{* * *}$ & 0.2015 & 0.1501 \\
\hline & All & 0.1528 & 0.1201 & 0.1427 \\
\hline \multirow{3}{*}{$\begin{array}{c}\text { Ownership Con- } \\
\text { centration }\end{array}$} & Diversified & 0.6085 & 0.5915 & 0.1781 \\
\hline & High diversified & $0.5504^{* * *}$ & $0.5498^{* * *}$ & 0.1571 \\
\hline & All & 0.5936 & 0.5781 & 0.1748 \\
\hline \multirow[t]{3}{*}{ Board Size } & Diversified & 7.7308 & 7.0000 & 1.1428 \\
\hline & High diversified & 7.8826 & 7.0000 & 1.7292 \\
\hline & All & 7.7697 & 7.0000 & 1.3188 \\
\hline \multirow{3}{*}{$\begin{array}{l}\text { Board Indepen- } \\
\text { dence }\end{array}$} & Diversified & 4.5955 & 5.0000 & 1.8718 \\
\hline & High diversified & 4.4737 & 5.0000 & 2.1084 \\
\hline & All & 4.5643 & 5.0000 & 1.9348 \\
\hline \multirow{3}{*}{$\begin{array}{c}\text { Outside Block } \\
\text { Holding }\end{array}$} & Diversified & 0.5403 & 1.0000 & 0.4999 \\
\hline & High diversified & 0.5591 & 1.0000 & 0.4977 \\
\hline & All & 0.5508 & 1.0000 & 0.4977 \\
\hline \multicolumn{5}{|l|}{$\begin{array}{c}\text { Firm characteris- } \\
\text { tics: }\end{array}$} \\
\hline \multirow[t]{3}{*}{ Total Assets } & Diversified & 4376 & 2050 & 6509 \\
\hline & High diversified & $10582^{* * *}$ & $4055^{* * *}$ & 13988 \\
\hline & All & 5967 & 2399 & 9425 \\
\hline Sales & Diversified & 3906 & 2220 & 5131 \\
\hline
\end{tabular}




\begin{tabular}{|c|c|c|c|c|}
\hline & High diversified & $9689^{* * *}$ & $4244^{* * *}$ & 15824 \\
\hline & All & 5388 & 2568 & 9482 \\
\hline Leverage & Diversified & 0.6781 & 0.6434 & 0.3008 \\
\hline & High diversified & $0.6164^{* * *}$ & 0.6114 & 0.3282 \\
\hline & All & 0.6623 & 0.6364 & 0.309 \\
\hline Growth & Diversified & 0.166 & 0.1384 & 0.3417 \\
\hline & High diversified & 0.1698 & 0.136 & 0.3364 \\
\hline & All & 0.1669 & 0.1372 & 0.3402 \\
\hline Cash Holdings & Diversified & 0.0555 & 0.0085 & 0.3407 \\
\hline & High diversified & 0.0512 & $0.0103^{* * *}$ & 0.1257 \\
\hline & All & 0.0544 & 0.0088 & 0.3006 \\
\hline Tax/EBIT Ratio & Diversified & 0.1069 & 0.0717 & 0.1863 \\
\hline & High diversified & 0.1245 & 0.0793 & 0.1714 \\
\hline & All & 0.1114 & 0.0738 & 0.1827 \\
\hline
\end{tabular}

T-tests are used for comparisons of means, and Wilcoxon signed-rank tests are used for comparisons of medians. The ${ }^{* * *},{ }^{* *}$ and ${ }^{*}$ denote significance of differences at 1,5 and 10 percent levels, respectively.

Table 5 highlights the correlations among variables. The results indicate that inside ownership is negatively related to firm performance. Ownership concentration is also inversely associated with all performance measures. Although, these findings are in contrast to the earlier studies conducted in emerging countries (for instance Javid \& Iqbal, 2007; Shah, 2009) however, these are consistent with the expectations for group firms. Institutional ownership seems an influential factor and it is positively related to firm performance. Similarly, other corporate governance measures of board independence and outside block holding are also strongly positively associated with firm financial performance. The statistics of correlations and Variance inflation factors suggest the presence of no serious problem of multicollinearity among the explanatory variables ${ }^{8}$.

Table 6 reports the results of cross section Generalized Least Square regression. The results suggest that corporate ownership as the most influential factor in affecting firm performance in Pakistan. The statistics indicate that inside ownership is significantly negatively related to ROA-Oper \& ROA-Netas well as Tobin's Q consistent with divergence of interest effect and entrenchment effect. However, inside ownership squared is significantly positively related to firm performance consistent with incentives effect. In contrast to the findings of negative-positive-negative relationship as shown

8 For brevity, the results of Variance inflation factor (VIF) are not reported. 


\begin{tabular}{|c|c|c|c|c|c|c|c|c|}
\hline$\frac{0}{\tilde{n}}$ & & & & & & & & \\
\hline 莺 & & & & & & & & \\
\hline$\stackrel{\mathbb{N}}{\text { in }}$ & & & & & & & & \\
\hline 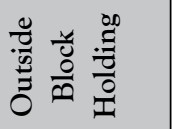 & & & & & & & & \\
\hline 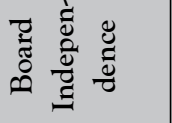 & & & & & & & & $\underset{8}{8}$ \\
\hline 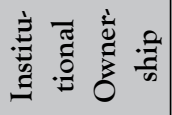 & & & & & & & ৪ & $\begin{array}{l}\tilde{\infty} \\
\cdots \\
0 \\
0\end{array}$ \\
\hline 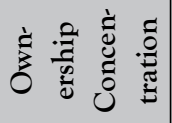 & & & & & & $\underset{8}{8}$ & $\begin{array}{l}8 \\
\vdots \\
\vdots \\
\end{array}$ & $\begin{array}{l}\tilde{o} \\
\hat{8} \\
\dot{0}\end{array}$ \\
\hline 光 & & & & & $\underset{8}{8}$ & $\begin{array}{l}\text { पे } \\
\text { 仓े } \\
\text { ñ } \\
0\end{array}$ & $\begin{array}{l}\text { पे } \\
\tilde{O} \\
0 \\
0\end{array}$ & $\underset{\substack{\pi \\
0}}{\mathbb{2}}$ \\
\hline 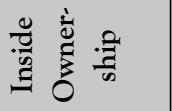 & & & & 8 & $\begin{array}{l}\infty \\
2 \\
\hat{a} \\
\dot{q}\end{array}$ & 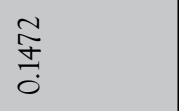 & $\begin{array}{l}n \\
\hat{q} \\
\tilde{q} \\
\dot{q}\end{array}$ & $\begin{array}{l}\stackrel{\widetilde{U}}{0} \\
\stackrel{0}{0}\end{array}$ \\
\hline$\stackrel{\infty}{\vdots} a$ & & & \begin{tabular}{l}
8 \\
8 \\
\hdashline \\
-
\end{tabular} & 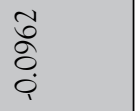 & \begin{tabular}{l}
0 \\
\multirow{2}{0}{} \\
0 \\
0
\end{tabular} & $\begin{array}{l}\tilde{\infty} \\
\stackrel{\infty}{0} \\
\dot{0}\end{array}$ & 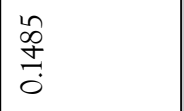 & $\begin{array}{l}\stackrel{0}{\Im} \\
\stackrel{2}{0}\end{array}$ \\
\hline 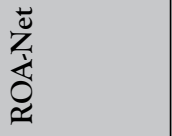 & & 8 & $\begin{array}{l}\infty \\
2 \\
2 \\
0 \\
0\end{array}$ & $\stackrel{\infty}{=}$ & 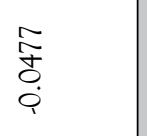 & $\frac{n}{n}$ & $\begin{array}{l}0 \\
8 \\
0 \\
0 \\
0\end{array}$ & $\begin{array}{l}0 \\
0 \\
0 \\
0 \\
0\end{array}$ \\
\hline 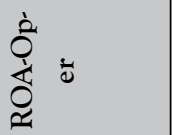 & $\underset{8}{8}$ & 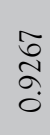 & $\begin{array}{c}2 \\
\grave{b} \\
\stackrel{0}{0} \\
0\end{array}$ & 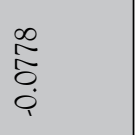 & $\begin{array}{l}\text { ț } \\
\text { ț } \\
0 \\
9\end{array}$ & $\begin{array}{l}\tilde{2} \\
\stackrel{1}{0}\end{array}$ & $\begin{array}{l}2 n \\
\hat{\sigma} \\
0 \\
0\end{array}$ & $\begin{array}{l}F \\
\text { fó } \\
\text { Oे }\end{array}$ \\
\hline$\frac{0}{\frac{\pi}{\frac{\pi}{2}}}$ & 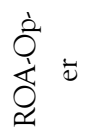 & 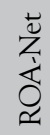 & $\begin{array}{c}a \\
-\infty \\
-\vdots \\
0 \\
0 \\
0\end{array}$ & 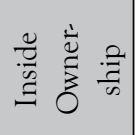 & 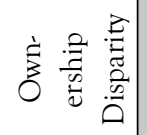 & 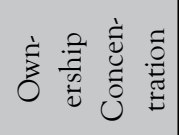 & 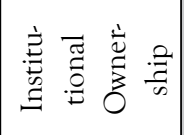 & 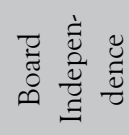 \\
\hline
\end{tabular}




\begin{tabular}{|c|c|c|c|}
\hline & & & $\underset{8}{8}$ \\
\hline & & $\underset{8}{8}$ & $\begin{array}{l}\overrightarrow{0} \\
\rightrightarrows \\
0\end{array}$ \\
\hline & ஓ & $\begin{array}{c}\infty \\
n \\
m \\
\dot{q}\end{array}$ & $\begin{array}{l}\hat{\widetilde{I}} \\
\stackrel{0}{0} \\
\dot{0}\end{array}$ \\
\hline$\underset{8}{8}$ & $\begin{array}{l}\stackrel{\circ}{\circ} \\
\stackrel{0}{0}\end{array}$ & $\begin{array}{c}\text { 寺 } \\
0 \\
0 \\
0\end{array}$ & 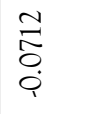 \\
\hline $\begin{array}{l}8 \\
\text { ठे } \\
0 \\
0\end{array}$ & 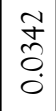 & $\begin{array}{l}0 \\
\hat{n} \\
0 \\
0 \\
0\end{array}$ & $\begin{array}{l}+ \\
2 \\
\infty \\
0 \\
0 \\
0\end{array}$ \\
\hline $\begin{array}{l}\stackrel{0}{\mathbb{N}} \\
\underset{0}{0}\end{array}$ & $\frac{\varkappa}{\sigma}$ & $\begin{array}{l}0 \\
0 \\
o \\
\dot{0} \\
\dot{0}\end{array}$ & $\begin{array}{l}\stackrel{ \pm}{ \pm} \\
\stackrel{0}{0} \\
\stackrel{0}{0}\end{array}$ \\
\hline 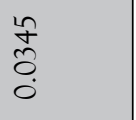 & $\begin{array}{c}\infty \\
0 \\
0 \\
0 \\
0\end{array}$ & $\begin{array}{l}\stackrel{+}{2} \\
\tilde{\sigma} \\
\dot{0}\end{array}$ & $\begin{array}{l}n \\
1 n \\
0 \\
0 \\
\dot{9}\end{array}$ \\
\hline $\begin{array}{l}\stackrel{\infty}{ \pm} \\
\stackrel{\infty}{ \pm}\end{array}$ & $\begin{array}{l}0 \\
0 \\
0 \\
0 \\
0\end{array}$ & $\begin{array}{l}\tilde{n} \\
8 \\
0 \\
\dot{8}\end{array}$ & $\begin{array}{l}2 \\
\widetilde{8} \\
\stackrel{0}{0}\end{array}$ \\
\hline 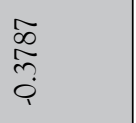 & 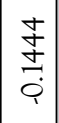 & $\begin{array}{l}\overline{8} \\
\overrightarrow{0} \\
0\end{array}$ & $\begin{array}{l}\infty \\
0 \\
0 \\
0 \\
0\end{array}$ \\
\hline $\begin{array}{l}\tilde{\approx} \\
\stackrel{-}{0}\end{array}$ & $\mid \begin{array}{c}\tilde{\infty} \\
0 \\
0 \\
0\end{array}$ & 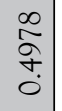 & $\begin{array}{l}\overrightarrow{\widetilde{J}} \\
0 \\
\dot{\varphi}\end{array}$ \\
\hline $\begin{array}{l}\text { tu } \\
\text { fo } \\
\stackrel{0}{0}\end{array}$ & $\mid \begin{array}{l}\infty \\
0 \\
\simeq \\
0 \\
0\end{array}$ & $\begin{array}{c}\vec{\sigma} \\
\text { m. } \\
\dot{1}\end{array}$ & 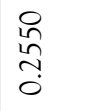 \\
\hline $\begin{array}{l}\stackrel{0}{7} \\
\stackrel{7}{0} \\
\stackrel{0}{0}\end{array}$ & $\mid \begin{array}{c}0 \\
0 \\
0 \\
0 \\
0\end{array}$ & 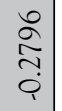 & 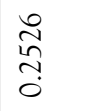 \\
\hline 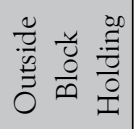 & $\stackrel{\mathscr{N}}{\tilde{D}}$ & 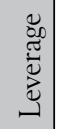 & $\frac{\mathscr{y}}{\tilde{N}} \frac{5}{0}$ \\
\hline
\end{tabular}


in the study of Arshad and Javid (2014), the present study finds an empirical evidence of negative-positive relationship between inside ownership and group affiliated firms' performance in Pakistani context. The results suggest that inside ownership negatively affects firm performance until it reaches at a certain threshold level and beyond that level it starts to affect positively the firm performance. Ownership concentration appears strongly negatively affecting both accounting and market performance of the firms. The findings are consistent with the expectations (for group firms) and however, inconsistent with the earlier studies of Javid and Iqbal (2007) and Shah (2009).

Table 6: Panel Data Analysis Results

\begin{tabular}{|c|c|c|c|c|c|c|}
\hline \multirow[t]{2}{*}{ Variable } & \multicolumn{2}{|c|}{ ROA-Oper } & \multicolumn{2}{|c|}{ ROA-Net } & \multicolumn{2}{|c|}{ Tobin's Q } \\
\hline & Model 1 & Model 2 & Model 1 & Model 2 & Model 1 & Model 2 \\
\hline \multirow{2}{*}{$\begin{array}{c}\text { Inside Own- } \\
\text { ership }\end{array}$} & $-0.1900^{* * *}$ & $-0.1823^{* * *}$ & $-0.2177^{* * *}$ & $-0.2076^{* * *}$ & -0.3274 & -0.3008 \\
\hline & $(0.0052)$ & $(0.0073)$ & $(0.0002)$ & $(0.0004)$ & $(0.2264)$ & $(0.2640)$ \\
\hline \multirow{3}{*}{$\begin{array}{c}\text { Inside } \\
\text { Ownership } \\
\text { Squared }\end{array}$} & $0.1929^{* *}$ & $0.1857^{* *}$ & $0.2115^{* * *}$ & $0.1996^{* * *}$ & 0.3965 & 0.4153 \\
\hline & & & & & & \\
\hline & $(0.0149)$ & $(0.0203)$ & $(0.0021)$ & $(0.0041)$ & $(0.2104)$ & $(0.1919)$ \\
\hline \multirow{2}{*}{$\begin{array}{c}\text { Ownership } \\
\text { Disparity }\end{array}$} & $-0.0387^{* * *}$ & $-0.0403^{* * *}$ & $-0.0423^{* * *}$ & $-0.0440^{* * *}$ & 0.0578 & 0.0512 \\
\hline & $(0.0106)$ & $(0.0078)$ & $(0.0011)$ & $(0.0007)$ & $(0.3274)$ & $(0.3830)$ \\
\hline \multirow{2}{*}{$\begin{array}{l}\text { Institution- } \\
\text { al Owner- } \\
\text { ship }\end{array}$} & 0.0309 & 0.0270 & 0.0297 & 0.0256 & $0.4066^{* * *}$ & $0.3836^{* * *}$ \\
\hline & $(0.3404)$ & $(0.4065)$ & $(0.2838)$ & $(0.3563)$ & $(0.0013)$ & $(0.0023)$ \\
\hline \multirow{2}{*}{$\begin{array}{l}\text { Ownership } \\
\text { Concentra- } \\
\text { tion }\end{array}$} & $-0.0600^{* *}$ & $-0.0582^{*}$ & $-0.0707^{* * *}$ & $-0.0677^{* *}$ & -0.1867 & -0.1932 \\
\hline & $(0.0524)$ & $(0.0610)$ & $(0.0093)$ & $(0.0132)$ & $(0.1394)$ & $(0.1250)$ \\
\hline \multirow{2}{*}{$\begin{array}{l}\text { Board Inde- } \\
\text { pendence }\end{array}$} & & 0.0037 & & $0.0046^{* *}$ & & $0.0204^{* *}$ \\
\hline & & $(0.1288)$ & & $(0.0268)$ & & $(0.0314)$ \\
\hline \multirow{3}{*}{$\begin{array}{c}\text { Outside } \\
\text { Block } \\
\text { Holding }\end{array}$} & & 0.0017 & & -0.0007 & & 0.0498 \\
\hline & & & & & & \\
\hline & & $(0.8652)$ & & $(0.9403)$ & & $(0.2140)$ \\
\hline Size & $0.0119^{* * *}$ & $0.0118^{* * *}$ & $0.0064^{*}$ & $0.0061^{*}$ & $-0.0752^{* * *}$ & $-0.0754^{* * *}$ \\
\hline
\end{tabular}




\begin{tabular}{|c|c|c|c|c|c|c|}
\hline & $(0.0024)$ & $(0.0026)$ & $(0.0665)$ & $(0.0778)$ & $(0.0000)$ & $(0.0000)$ \\
\hline \multirow[t]{2}{*}{ Leverage } & $-0.0722^{* * *}$ & $-0.0736^{* * *}$ & $-0.1102^{* * *}$ & $-0.1114^{* * *}$ & $1.1365^{* * *}$ & $1.1241^{* * *}$ \\
\hline & $(0.0000)$ & $(0.0000)$ & $(0.0000)$ & $(0.0000)$ & $(0.0000)$ & $(0.0000)$ \\
\hline \multirow{2}{*}{$\begin{array}{c}\text { Sales } \\
\text { Growth }\end{array}$} & $0.0669^{* * *}$ & $0.0679^{* * *}$ & $0.0621^{* * *}$ & $0.0633^{* * *}$ & 0.0170 & 0.0230 \\
\hline & $(0.0000)$ & $(0.0000)$ & $(0.0000)$ & $(0.0000)$ & $(0.5978)$ & $(0.4738)$ \\
\hline \multirow[t]{2}{*}{ Constant } & 0.0307 & 0.0118 & $0.0787^{*}$ & 0.0564 & $1.0020^{* * *}$ & $0.8842^{* * *}$ \\
\hline & $(0.5244)$ & (0.8108) & $(0.0671)$ & (0.1995) & $(0.0000)$ & $(0.0000)$ \\
\hline $\begin{array}{l}\text { No. of ob- } \\
\text { servations }\end{array}$ & 964 & 964 & 964 & 964 & 964 & 964 \\
\hline No. of firms & 184 & 184 & 184 & 184 & 184 & 184 \\
\hline $\begin{array}{l}\text { Industry } \\
\text { dummies }\end{array}$ & Included & Included & Included & Included & Included & Included \\
\hline $\begin{array}{l}\text { Adjusted } \\
\text { R-squared }\end{array}$ & 0.1085 & 0.1094 & 0.1855 & 0.1880 & 0.3320 & 0.3347 \\
\hline F-statistic & $6.0964^{* * *}$ & $5.7303^{* * *}$ & $10.5374^{* * *}$ & $9.9210^{* * *}$ & $21.8092^{* * *}$ & $20.3757^{* * *}$ \\
\hline $\begin{array}{l}\text { Rho: } \\
\text { Cross-sec- } \\
\text { tion } \\
\text { random }\end{array}$ & 0.3424 & 0.3388 & 0.4124 & 0.4116 & 0.4744 & 0.4664 \\
\hline $\begin{array}{c}\text { Hausman: } \\
\text { Cross-sec- } \\
\text { tion } \\
\text { random }\end{array}$ & $25.4965^{* * *}$ & $29.1369^{* * *}$ & $24.8471^{* * *}$ & $27.9005^{* * *}$ & $160.2820^{* * *}$ & $165.5236^{* * *}$ \\
\hline
\end{tabular}

are in parentheses. The table reports the results of random-effect generalized least squares panel estimation.

Moreover, ownership disparity (excess control) is strongly negatively related to both ROA-Oper and ROA-Net. However, the ownership disparity shows an insignificant relationship with Tobin's $\mathrm{Q}$. The findings highlight a major problem in the governance landscape of Pakistani business groups' affiliated firms that these firms fall into serious agency conflicts among the controlling shareholders and external shareholders. The results confirm that higher the disparity (wedge) between ownership and control, greater the potential of tunneling firm resources at the expense of minority shareholders by the ultimate controllers in the group firms (Baek et al., 2006; Attig, 2007). The ultimate controllers are fully entrenched with least capital investments and they are motivated in expropriation of minority shareholders (Bebchuck, 2000; Bertrand, 2002; Lee et al, 2008; Dow \& McGuire, 2009). 
The coefficients of institutional ownership are consistently positive in all of the regression models. The results are highly significant and however, the strength of relationship is stronger in Tobin's $Q$ regression results. The institutional investors possess the ability and motivation in monitoring of the firm and further their interests are aligned with minority shareholders. The findings confirm that institutional investors play a vital role in mitigating agency conflicts among controlling shareholder and minority shareholders. These results are consistent with earlier researchers like Shah (2009), Javid and Iqbal (2007) and Abdullah, Shah, Iqbal, \& Gohar (2011b) .

Moreover, board independence is strongly positively related to ROA-Oper, ROANet \& Tobin's $Q$ in all of the regression models. The presence of outside directors in the board enhances the ability of firm in monitoring the activities of the management and quality of decision making (Fama \& Jensen, 1983). Finally, outside block holding positively affects firm performance. The findings suggest that presence of outside block holders is helpful in reducing the entrenchment effects of ultimate controllers in the group firms. The results show a significant negative impact of leverage on ROA-Oper $\&$ ROA-Net whereas significantly positive impact on Tobin's $Q$. The positive relationship is consistent with the argument that financial leverage brings the firm under the monitoring of the financial institutions as well and it aligns their interests with minority shareholders. Similarly, consistent with the expectations, the study finds a positive impact of growth and firm size on group firms' performance in Pakistan.

\section{Conclusion}

The study shed light into three major issues. Firstly, how corporate ownership affects firm performance and secondly it examines the explanatory power of corporate governance practices to firm financial performance in Pakistan. Thirdly and most importantly, the study explores the performance impacts of excess control (ownership-control disparity) in Pakistani context. The results of 964 firm yearly observations suggest that ownership structure, excess control and corporate governance play a vital role in affecting firm performance. The group firms fall into severe agency problem between controlling shareholders and minority shareholders. Although, many researchers propose that ownership concentration is a response of weak regulatory system in the country and it affect positively to firm performance (La Porta et al., 1999; Javid $\&$ Iqbal, 2007). But, the present study finds evidence of the negative performance impacts of ownership concentration.

Further, ownership disparity negatively affects firm performance consistent with divergence of interest effect. The ultimate controllers of group firms attempt controlling many firms simultaneously with least cash flows invested by using complex ownership and pyramidal structures. The greater the disparity between ownership 
and control, the higher the potential of tunneling firm resources for the ultimate controller because any discount in market prices of shares will cost him least. It stresses the need for the development of a sound financial system in a country that benefits should flow to the shareholders in proportion to their investments.

In a country with weak legal institutional environment, internal monitoring becomes essential for the protection of external shareholders. The institutional investors and outside block holders are the major tools of monitoring management activities and these are sources of controlling agency conflicts among controlling shareholders and minority shareholders (as their interests are aligned with minority shareholders). The findings confirm a significant positive role of both institutional investors and outside block holders in affecting firm performance. Further, board independence seems strongly positively affecting firm performance. The findings highlight major corporate governance problems faced by group affiliated firms and suggest various measures to resolve the issues. The findings show strong implications for policy makers and practitioners. These stresses the need for effective monitoring system for the protection of minority shareholders in Pakistan.

\section{References}

Abdullah, F., Shah, A., Iqbal, A. M., \& Gohar, R. (2011a). The effect of group and family ownership on firm performance. Empirical evidence from Pakistan. International Review of Business Research Papers, 7(4), 177-194.

Abdullah, F., Shah, A., Iqbal, A. M., \& Gohar, R. (2011). Investors' power and the dividend cost minimization model: Which one better explains the dividend policy in Pakistan? African Journal of Business Management, 5(26), 10747.

Abdullah, F., Shah, A., \& Khan, S. U. (2012). Firm performance and the nature of agency problems in insiders-controlled firms: Evidence from Pakistan. The Pakistan Development Review, 161-182.

Ali, A., Chen, T. Y., \& Radhakrishnan, S. (2007). Corporate disclosures by family firms. Journal of Accounting and Economics, 44(1-2), 238-286.

Andres, C. (2006). Family ownership as the optimal organizational structure? Retrieved from http://www. efmaefm.org/OEFMAMEETINGS/EFMA Annual MEETING/2006-Madrid/papers/976279_full. pdf

Arshad, H., \& Javid, A. Y. (2014). Does inside ownership matters in financial decisions and firm performance: Evidence from manufacturing sector of Pakistan. Retrieved from https://www.pide.org. $\mathrm{pk} / \mathrm{pdf} /$ working\%20paper/workingpaper-107.pdf

Attig, N., Fischer, K. P., \& Gadhoum, Y. (2004). On the determinants of pyramidal ownership: Evidence on dilution of minority interests. Retrieved from https://www.papers.ssrn.com/so13/papers. 
cfm?abstract_id $=434201$

Attig, N. (2007). Excess control and the risk of corporate expropriation: Canadian evidence. Canadian Journal of Administrative Sciences, 24, 94-106.

Baek, J. S., Kang, J. K., \& Lee, I. (2006). Business groups and tunneling: Evidence from private securities offerings by Korean chaebols. Journal of Finance, 61, 2415-2449.

Baysinger, B. D., \& Butler, H. N. (1985). Corporate governance and the board of directors: Performance effects in board composition. Journal of Law, Economics and Organization, 1(1), 101-124.

Bebchuk, L., Kraakman, R. \& Triantis, G. (2000). Stock pyramids, cross-ownership, and dual class equity: The creation and agency costs of separating control from cash flow rights. In R. Morck (Ed.) Concentrated corporate ownership. (pp. 295-318). Chicago, IL: University of Chicago Press.

Bennedsen, M., \& Nielsen, K. M. (2010). Incentive and entrenchment effects in European ownership. Journal of Banking $\mathcal{E}$ Finance, 34(9), 2212-2229.

Berle, A. A., \& Means, G. C. (1932). The modern corporation and private property. New York: MacMillan.

Bertrand, M., Mehta, P., \& Mullainathan, S. (2002). Ferreting out tunneling: An application to Indian business groups. Quarterly Journal of Economics, 117(1), 121-48.

Bertrand, M., Johnson, S., Samphantharak, K. \& Schoar, A. (2008). Mixing family with business: A study of Thai business groups and the families behind them. Journal of Financial Economics, 88, 466-498.

Bozec, Y., \& Laurin, C. (2004). Concentration des droits de propriété, séparation entre participation au capital et contrôle des votes et performance opérationnelle des societies: Une etude canadienne. Finance Contrôle Stratégie, 7, 123-164.

Bozec, Y., \& Laurin, C. (2008). Large shareholder entrenchment and performance: Empirical evidence from Canada. Journal of Business Finance $\mathcal{E}$ Accounting, 35(12), 25-49.

Carney, M., Shapiro, D., \& Tang, Y. (2009). Business group performance in China: Ownership and temporal considerations. Management and Organization Review, 5(2), 167-193.

Claessens S., Djankov, S., \& Lang, L. (2000). The separation of ownership and control in East Asian corporations. Journal of Financial Economics, 58(1), 81-112.

Claessens, S., Djankov, S., Fan, J., \& Lang, L. (2002). Disentangling the incentive and entrenchment effects of large shareholdings. Journal of Finance, 57(6), 2741-71.

Cornett, M. (2008). Corporate governance and pay for performance: The impact of earnings management. Journal of Financial Economics, 87, 357-373.

Dedman, E. (2002). The Cadbury Committee recommendations on corporate governance-A review of compliance and performance impacts. International Journal of Management Reviews, 4(4), 335- 352.

Demsetz, H., \& Lehn, K. (1985). The structure of corporate ownership: Causes and consequences. 
Journal of Political Economy, 93(6), 1155-1177.

Djankov, S., LaPorta, R., Lopez-de-Silanes, F., \& Shleifer, A. (2008). The law and economics of self-dealing. Journal of Financial Economics, 88, 430-465.

Dow, S., \& McGuire, J. (2009). Propping and tunneling: Empirical evidence from Japanese keiretsu. Journal of Banking E⿱ Finance, 33, 1817-1828.

Essen, M. V. (2011). An institution-based view of ownership. Doctoral dissertation, Erasmus University, Rotterdam, Netherlands.

Estrin, S., Poukliakova, S., \& Shapiro, D. (2009). The performance effects of business groups in Russia. Journal of Management Studies, 46(3), 393-420.

Fama, E., \& Jensen, M. (1983). Separation of ownership and control. Journal of Law and Economics, 26, 301-327.

George, R., \& Kabir, R. (2008). Corporate diversification and firm performance: How does business group affiliation matter? Retrieved from http://www.demo.uib.es/IBEW/IBEW-2008/Papaers2008/ CorpDiv_BusGroups_July2008.pdf

Ghani, W. I., Haroon, O., \& Ashraf, J. (2008). Business groups, corporate governance, and financial performance: Evidence from Pakistan. Retrieved from http://www.cmer.lums.edu.pk/Conference2008/images/Waqar_G_Business_Groups.pdf

Gohar, R., \& Karacaer, S. (2009). Pakistani business groups: A comparison of group affiliated and unaffiliated firm performance. NUST Journal of Business and Economics, 2(2), 41-53.

He, J., Mao, X., Rui, O. M., \& Zha, X. (2013). Business groups in China. Journal of Corporate Finance, 22(1), 166-192.

Hsu, C., \& Liu, H. (2008). Corporate diversification and firm performance: The Moderating role of contractual manufacturing model. Asia Pacific Management Review, 13(1), 345-360.

Hutchinson, M., \& Gul, F. A. (2004). Investment opportunity set, corporate governance practices and firm performance. Journal of Corporate Finance, 10(4), 595-614.

Ikram, A., \& Naqvi, S. A. A. (2005). Family business groups and tunneling framework: Application and Evidence from Pakistan. Retrieved from http://www.saber.eaber.org/sites/default/files/ documents/LUMS_Ikram_2005.pdf

Javid, A. Y., \& Iqbal, R. (2007). Relationship between corporate governance indicators and firm performance in case of Karachi Stock Exchange. Retrieved from http://www.mpra.ub.uni-muenchen. de/2225/1/MPRA_paper_2225.pdf

Jensen, M., \& Meckling, W. (1976). Theory of the firm: Managerial behavior, agency costs and capital structure. Journal of Financial Economics 3, 305-360. 
Joh, S. W. (2003). Corporate governance and firm profitability: Evidence from Korea before the economic crisis. Journal of Financial Economics, 68(2), 287-322.

Khanna, T., \& Palepu, K. (1999). Emerging market business groups, foreign investors, and corporate governance. Retrieved from http://www.nber.org/papers/w6955.

Khanna, T., \& Palepu, K. (2000). The future of business groups in emerging markets: Long-run evidence from Chile. Academy of Management Journal, 43(3), 268-285.

Khanna, T., \& Rivkin, J. W. (2001). Estimating the performance effects of business groups in emerging markets. Strategic Management Journal, 22(1), 45-74.

Khanna, T., \& Yafeh, Y. (2005). Business groups and risk sharing around the world. Journal of Business, $78,301-340$.

Kim, H., Hoskisson, R. \& Wan, W. (2004). Power dependence, diversification strategy, and performance in keiretsu member firms. Strategic Management Journal, 25, 613-636.

King, M. R., \& Santor, E. (2008). Family values: Ownership structure, performance and capital structure of Canadian firms. Journal of Banking $\mathcal{E}$ Finance, 32(11), 2423-2432.

Klein, A. (1998). Firm performance and board committee structure. Journal of Law E Economics, 41(1), 275-299

Kyereboah-Coleman, A. (2007). Corporate governance and shareholder value maximization: An African perspective. African Development Review, 19(2), 350-367.

La Porta, R., Lopez-de-Silanes, F., \& Shleifer, A. (1999). Corporate ownership around the world. The Journal of Finance, 54(2), 471-517.

La Porta, R., Lopez-de-Silanes, F., Shleifer, A., \& Vishny, R. (2000). Investor protection and corporate governance. Journal of Financial Economics, 58, 3-27.

Lan, Y., \& Wang, N. (2004). Investor protection and investment. Retrieved from http://www.gsb. columbia.edu/faculty/wang/paper/InvestorProtection.pdf

Lee, K., Peng, M. W., \& Lee, K. (2008). From diversification premium to diversification discount during institutional transitions. Journal of World Business, 43(1), 47-65.

Leff, N. H. (1978). Industrial organization and entrepreneurship in the developing countries: The economic groups. Economic Development and Cultural Change, 26(4), 661-675.

Lemmon, M. L., \& Lins, K. V. (2003). Ownership structure, corporate governance, and firm value: Evidence from the East Asian financial crisis. The Journal of Finance, 58(4), 1445-1468.

Lins, K., \& Servaes, H. (2002). Is corporate diversification beneficial in emerging markets? Financial Management, 31, 5-31.

Lins, K. V. (2003). Equity ownership and firm value in emerging markets. Journal of Financial and Quan- 
titative Analysis, 38(1), 159-184.

Moulton, B. (1986). Random group effects and the precision of regression estimates. Journal of Econometrics, 32(3), 385-397.

Omrane, G., \& Dev, M. (2009). Excess control, corporate governance, and implied cost of equity: International Evidence. Financial Review, 44(4), 489-524.

Shah, S. Z. A. (2009). Corporate governance and financial performance: A comparative study of developing and developed markets. Doctoral dissertation, Capital University of Arts, Sciences and Technology, Islamabad, Pakistan.

Shahid-ur-Rehman (1998). Who owns Pakistan? Islamabad, Pakistan: Mr. Books (Pvt.) Ltd.

Shleifer, A., \& Vishny, R. W. (1986), Large shareholders and corporate control. Journal of Political Economy, 94(3), 461-488.

Shleifer, A., \& Vishny, R. (1997). A survey of corporate governance. Journal of Finance, 52(2), 737-783.

Villalonga, B., \& Amit, R. (2006). How do family ownership, control, and management affect firm value? Journal of Financial Economics, 80(2), 385-417.

White, L. (1974). Industrial concentration and economic power in Pakistan. Princeton University Press. Retrieved from http://www.jstor.org/stable/j.ctt13x12nt

Yin, X., \& Zajac, E. J. (2004). The strategy/governance structure fit relationship: Theory and evidence in franchising arrangements. Strategic Management Journal, 25(4), 365-383.

Young, S. (2000). The increasing use of non-executive directors: Its impact on UK board structure and governance arrangement. Journal of Business Finance $\mathcal{E}$ Accounting, 27(9), 1311-1342.

Yousaf, I., \& Hasan, A. (2016). Effect of family control on corporate financing decisions: A case of Pakistan. Retrieved from http://www.pide.org.pk/pdf/Working\%20Paper/WorkingPaper-138.pdf

Zeitun, R. (2009). Ownership structure, corporate performance and failure: evidence from panel data of emerging market: The case of Jordan. Corporate Ownership $\mathcal{E}$ Control, 6(4), 96-114. 